\title{
Mutual sentiment
}

\author{
Olga Maksimenko ${ }^{1}$, Tatiana Semina ${ }^{1, *}$, Alexander Khmelev ${ }^{1}$ and Natalia Dmitrieva ${ }^{1}$ \\ ${ }^{1}$ Moscow Region State University, 10A, Radio Str., 105005, Moscow, Russia
}

\begin{abstract}
Sentiment analysis is a modern task in natural language processing and linguistics. Also referred to as opinion mining, it deals with different kinds of affective states: opinion, emotions, stance and evaluations. Sentiment itself is the polarity of these affective states. Taking analytical articles as source material for the study, several problems should be considered. Firstly, these texts broaden the understanding of the subject of opinion, because it does not coincide with the author of the text in the majority of cases. Secondly, subjects and objects of opinion are entities words or word combinations with strictly denoted referent. In the paper only Named Entities, that are normally expressed by proper nouns, are considered. This kind of sentiment analysis requires deeper research of possible sentiment relations between entities and of lexical and grammatical influence on these relations. The paper is devoted to the study of the influence of the group of lexemes on opinion structure. The research shows that mutual sentiment can be presented as stable patterns.
\end{abstract}

\section{Introduction}

Sentiment analysis, also known as opinion mining, refers to the study of opinions, evaluations, emotions and other kinds of affective states towards objects like goods, service, events or named entities. The purpose of sentiment analysis is the identification and extraction of main components of opinion and the sentiment, the polarity of the expressed opinion.

The subject (or a source) of opinion is a person, expressing the opinion [1-3], while the objects and situations, the opinion is expressed towards, are referred to as the object of opinion or the target of opinion. Apart from these components of opinion, a sentiment landmark, concerning that the opinion is denoted, can be included in opinion structure. Sentiment lexicon, that explicitly presents the opinion, does not always belong to the class of affective words. Factual lexemes, that express benefactive or malefactive (also referred to as good for and bad for) events, are sentiment words as well $[4,5]$. Sentiment lexemes are recorded in special lexicons, that can be presented as lists of positive and negative words or as a more complicated resource with additional information for each unit [6]. Several lexicons are available for the Russian language, they differ in the approach to creation and in the words included [7,8]. Another type of linguistic resource for sentiment analysis is a bank of connotation frames, that depict specific sentiment connotations for lexical units [9-11].

\footnotetext{
${ }^{*}$ Corresponding author: taniasemina@gmail.com
} 
Subject of opinion in news and analytical articles may not coincide with the author, it can be expressed by an element inside the text, called the entity. The entity is a lexical unit with defined referent, possible types of entities are person, location, geopolitical unit, mass media, etc. [12]. In news and analytical articles entities in texts may occur on sentiment relations, but this opinion would differ from the traditional notion of evaluation in lexical and structural features. Sentiment includes evaluation and a group of other affective states as stance and attitude [13-15].

Lexical units may complicate opinion expression, and the interfering words are not necessary included in the class of sentiment words. The problem of sentiment inversion as a result of negation has been investigated [16-19], but still the problem pf mutual or bidirectional sentiment was not yet discussed.

\section{Methods}

Mutual sentiment is a situation with bidirectional sentiment attitudes between two entities with the same polarity of opinion. Considering mutual sentiment as a distinct case of opinion enables the researchers to indicate part of implicit sentiment. Thus, the problem of the representation of mutual sentiment in texts arises. Accordingly, there are two components of opinion in the same text span, while their status may be different. In some ways they may be considered as equal, on the other hand, data show that there can be examples with one entity being a more highlighted subject, although, the object reflects the opinion towards the subject. The components of opinion will be referred to as entities, as in the course of analysis only Named Entities (people, location, government etc.) were taken into consideration.

There are two equal sentiment attitudes in (1). The subject of the first opinion is Turtsiya 'Turkey' and the object is Rossiya 'Russia', the second opinion represents the reversed attitude, but the polarity of opinion does not change.

(1) Turtsiya i Rossiya potselovalis i pomirilis.

'Turkey and Russia kissed each other and reconciled.'

The opinions are fixed according to the components, including the subject, the object, the sentiment and the explicit sentiment expression (Table 1). Not only the sentiment is the same for both opinions, but also the sentiment expression.

Table 1. Sentiment attitudes from Example (1).

\begin{tabular}{|l|l|l|l|}
\hline \multicolumn{1}{|c|}{ Subject } & \multicolumn{1}{|c|}{ Object } & \multicolumn{1}{c|}{ Sentiment } & \multicolumn{1}{c|}{ Sentiment expression } \\
\hline $\begin{array}{l}\text { Turtsiya } \\
\text { 'Turkey' }\end{array}$ & $\begin{array}{l}\text { Rossiya } \\
\text { 'Russia' }\end{array}$ & positive & $\begin{array}{l}\text { potselovalis i pomirilis } \\
\text { 'kissed each other and } \\
\text { reconciled' }\end{array}$ \\
\hline $\begin{array}{l}\text { Rossiya } \\
\text { 'Russia' }\end{array}$ & $\begin{array}{l}\text { Turtsiya } \\
\text { 'Turkey' }\end{array}$ & positive & $\begin{array}{l}\text { potselovalis i pomirilis } \\
\text { 'kissed each other and } \\
\text { reconciled' }\end{array}$ \\
\hline
\end{tabular}

Mutual sentiment can be expressed explicitly by a specific group of words, that can be included in sentiment lexicons as well, for instance, raznoglasie 'disagreement' and sotrudnichestvo 'cooperation'. They both are the units of RuSentiLex lexicon, where they have negative and positive sentiment, respectively [8]. However, the lexicon does not represent their ability to impose bidirectional sentiment attitudes on two entities. It is to be noticed, that this information is partly implemented in connotation frames, thought they are difficult to develop. 
Lexemes, that impose mutual sentiment, may not be considered as affective. For example, otnosheniya 'relations' imposes mutual sentiment on two entities, but lacks the polarity of opinion. Therefore, non-affective indicators of mutual sentiment need to be followed by a sentiment expression to indicate the polarity.

In order to extract the examples of mutual sentiment from the data, a nuclear set of indicators of mutual sentiment was compiled by the experts, later that set was expanded. The nuclear set consisted of the words otnosheniya 'relations', svyaz 'connection', sotrudnichestvo 'cooperation', raznoglasie 'disagreement' and soyuznik 'associate', all the words except otnosheniya 'relations' were extracted from normalized texts, the normalization was done with PyMorphy2 package and included punctuation removal using regular expressions. The nuclear set was compiled by browsing the frequency dictionary, created for the corpus of analytical articles. The whole corpus consists of 120 articles or 5745 sentences, 257 sentences with words from the nuclear set were extracted, 73 of them included the word form otnosheniya 'relations'. The nuclear set consists of both affective (sotrudnichestvo 'cooperation', soyuznik 'associate', raznoglasie 'disagreement') and neutral words (otnosheniya 'relations', svyaz 'connection').

Therefore, sentiment attitudes may not be expressed in these examples, so the further analysis was conducted manually in order to find different patterns of mutual sentiment expression. The preliminary analysis showed, that opinions in analytical texts tend to be expressed within the sentence, and that the indicators impose mutual sentiment on a limited text span, consequently, the analysis continued, and the set of indicators was expanded with the use of thesaurus of Russian RuWordNet [20]. Every source word (Table 2) was followed by its cognate words, hyponims, hyperonims and synonyms.

Table 2. Basic list extension.

\begin{tabular}{|l|l|l|l|l|}
\hline \multicolumn{1}{|c|}{ Source word } & \multicolumn{1}{|c|}{ Cognate words } & \multicolumn{1}{|c|}{ Hyponyms } & \multicolumn{1}{|c|}{ Hyperonyms } & \multicolumn{1}{|c|}{ Synonyms } \\
\hline $\begin{array}{l}\text { sotrudnichestvo } \\
\text { 'cooperation' }\end{array}$ & $\begin{array}{l}\text { Sotrudnichat' } \\
\text { 'cooperate' }\end{array}$ & $\begin{array}{l}\text { partnerstvo } \\
\text { 'partnership' } \\
\text { druzhba } \\
\text { 'friendship' }\end{array}$ & $\begin{array}{l}\text { vzaimodeystvie } \\
\text { 'interaction' }\end{array}$ & $\begin{array}{l}\text { Sotrudnichat' } \\
\text { 'cooperate' }\end{array}$ \\
\hline $\begin{array}{l}\text { soyuznik } \\
\text { 'associate' }\end{array}$ & $\begin{array}{l}\text { soyuznitsa } \\
\text { 'female associate' }\end{array}$ & - & - & $\begin{array}{l}\text { pomoschnik } \\
\text { 'mate' }\end{array}$ \\
\hline $\begin{array}{l}\text { svyaz } \\
\text { 'connection' }\end{array}$ & - & - & - & - \\
\hline $\begin{array}{l}\text { raznoglasie } \\
\text { 'disagreement' }\end{array}$ & - & $\begin{array}{l}\text { vrazhda } \\
\text { 'enmity' } \\
\text { spor } \\
\text { 'dispute' } \\
\text { konflikt } \\
\text { 'conflict' }\end{array}$ & - & rashozhdenie \\
'discrepancy'
\end{tabular}

Several lexemes (Table 2) were not expanded, because some lexemes in the thesaurus did not have the property of mutual sentiment imposition. For example, the word svyaz 'connection' has cognate words svyazyivatsya 'to contact' and svyazatsya 'to contact', therefore these words cannot be the indicators of mutual sentiment.

The frequency of several lexemes should be taken into account, units sotrudnichestvo 'cooperation', svyaz 'connection' and soyuznik 'associate' had high frequency in the collected corpus, their absolute frequencies range from 60 to 90 , for vzaimodeystvie 'interaction' and raznoglasie 'disagreement' the absolute frequencies are 18 and 22, respectively. The lexeme otnosheniye 'relation' has absolute frequency of 298 , but the lexeme cannot be considered as the indicator because of ambiguity, connected with the coincidence of word forms of the noun otnosheniye 'relation' and a part of prepositions po otnosheniyu and $v$ otnoshenii 'towards'. In order to eliminate the ambiguity, only the word 
form otnosheniya 'relations' was included into the set of indicators, because it does not match any other word form of the prepositions.

Nuclear set expansion lead to adding 89 examples of sentences that may have mutual sentiment, consequently, $25,7 \%$ of the whole set of examples were extracted using thesaurus. The analysis showed, that several pattern of mutual sentiment can be distinguished and designed, according to the way the objects of opinion and the indicator of mutual sentiment are located.

The SOOS label was set to indicate mutual sentiment in the examples, the label can be deciphered as Subject-Object \& Object-Subject, denoting, that there are two sentiment relations between two entities, in the first sentiment relation Entity ${ }_{1}$ is the subject, in the second one - the object, Entity ${ }_{2}$ behaves in a reversed way. The sentiment itself, or the polarity of opinion (positive or negative), is supposed to match, because it is explicitly expressed by one sentiment expression.

Three possible patterns of two entities and the indicator of mutual sentiment were identified, sentiment and non-sentiment indicators were not distinguished in the course of analysis. Moreover, the inequality of entities in mutual sentiment was not treated individually. The inequality means that one of the entities is the subject of opinion, and another entity just reflects the sentiment. If both entities are equal, in the course of sentiment analysis two opinions are extracted, and they both are considered to be equal in the strength of sentiment.

Three possible patterns were identified:

1. The indicator of mutual sentiment is located between the entities;

2. The indicator of mutual sentiment precedes the entities;

3. The indicator of mutual sentiment follows the entities.

\subsection{Named Entity-SOOS-Named Entity}

The contexts of the first pattern are shown in Table 3. Each pattern is followed by the indicators of mutual sentiment and the grammatical cases of the named entities.

Table 3. Structure of the pattern Named Entity-SOOS-Named Entity.

\begin{tabular}{|l|l|l|l|}
\hline $\begin{array}{c}\text { Named } \\
\text { Entity \{case\} }\end{array}$ & \multicolumn{1}{|c|}{ Indicators of mutual sentiment } & $\begin{array}{c}\text { Named Entity } \\
\text { \{case\} }\end{array}$ \\
\hline NE \{nomn\} & $\begin{array}{l}\text { sotrudnichat's } \\
\text { 'cooperate with' } \\
\text { druzhit's } \\
\text { 'be friends with' }\end{array}$ & NE \{ablt\} \\
\hline NE \{nomn\} & Verb & $\begin{array}{l}\text { partnerstvo s 'partnership with' } \\
\text { vzaimodejstvie s 'interaction } \\
\text { with' } \\
\text { otnosheniya s 'relations with' } \\
\text { svyazi s 'connections with' } \\
\text { sotrudnichestvo s 'cooperation } \\
\text { with' } \\
\text { druzhba s 'friendship with' }\end{array}$ & (ablt\} \\
\hline NE \{nomn\} & $\begin{array}{l}\text { soyuznik 'associate' } \\
\text { partner 'partner' } \\
\text { vrag 'enemy' } \\
\text { drug 'friend' }\end{array}$ & NE \{gent\} \\
\hline
\end{tabular}

The most frequent type of relations between entities in the first pattern can be depicted as $[\mathrm{NE}\{$ nomn $\} \leftarrow \rightarrow \mathrm{NE}\{$ ablt $\}$ ]. It means that the first entity is in nominative case and the second one is in ablative. The first nominative entity is the grammatical subject of the 
clause, the second one has the role of the object in ablative, the case is provided by the pronoun $s$ 'with' after the indicators of mutual sentiment.

The structure in (2) is not typical for the pattern, but it is caused by the restrictions imposed on the first entity by the modal indicator nuzhno 'need', the agent of that cannot stand in the nominative case.

\section{(2) NE \{datv\} nuzhno sotrudnichat's NE \{ablt\}}

$N E\{$ datv\} 'need to collaborate with' $N E\{a b l t\}$

We need to note, it is doubtless that all bidirectional sentiment relations cannot be distinguished by the search of the indicators of mutual sentiment and grammatical cases of the named entities. However, even nowadays sentiment analysis systems do not take mutual sentiment into consideration, although this kind of relation is evident for native speakers. Lists of possible indicators of mutual sentiment followed by a set of rules would have positive effect on results of opinion mining.

The context (3), not included in the main pattern, should be considered. It follows the mai pattern structure with a single exception, as the entity in nominative and the entity in ablative have the third entity in accusative between them. The first entity $\left(\mathrm{NE}_{1}\right)$ affects the second one $\left(\mathrm{NE}_{2}\right)$ to suspend cooperation with the third entity $\left(\mathrm{NE}_{3}\right)$.

(3) $N E_{1}\left\{\right.$ nomn\} zastavila $\mathrm{NE}_{2}$ \{accs\} priostanovit aktivnoe sotrudnichestvo $\mathrm{s} \mathrm{NE}_{3}$ $\{a b l t\}$

' $N E_{1}\{$ nomn $\}$ forced $N E_{2}\{a c c s\}$ to suspend active cooperation with $N E_{3}\{a b l t\}$ '

Table 4 represents all sentiment relation between the entities in (3), and the pattern [NE \{nomn $\} \leftarrow \rightarrow \mathrm{NE}\{$ ablt\}], can be used for mining part of opinions expressed.

Table 4. Opinion structure of (3).

\begin{tabular}{|c|c|c|c|c|}
\hline № & $\begin{array}{l}\text { Subject of } \\
\text { opinion }\end{array}$ & $\begin{array}{c}\text { Object of } \\
\text { opinion }\end{array}$ & Explicit information & Implicit information \\
\hline 1 & $\begin{array}{l}\text { Named } \\
\text { Entity } 2\end{array}$ & $\begin{array}{l}\text { Named } \\
\text { Entity } 3\end{array}$ & $\begin{array}{l}\text { Named Entity } 2 \text { used to } \\
\text { cooperate with Named } \\
\text { Entity } 3 \text {. }\end{array}$ & $\begin{array}{l}\text { Negative sentiment of Named } \\
\text { Entity } 2 \text { towards Named Entity } 3 \\
\text { cannon be easily established, } \\
\text { because suspending of cooperation } \\
\text { was not the desire of Named } \\
\text { Entity } 2 \text {. }\end{array}$ \\
\hline 2 & $\begin{array}{l}\text { Named } \\
\text { Entity } 1\end{array}$ & $\begin{array}{l}\text { Named } \\
\text { Entity } 3\end{array}$ & $\begin{array}{l}\text { Named Entity } 1 \text { made } \\
\text { Named Entity } 2 \text { spoil } \\
\text { relations with Named } \\
\text { Entity } 3 .\end{array}$ & $\begin{array}{l}\text { Named Entity } 1 \text { is negative } \\
\text { towards Named Entity } 3 \text {. }\end{array}$ \\
\hline 3 & $\begin{array}{l}\text { Named } \\
\text { Entity } 3\end{array}$ & $\begin{array}{l}\text { Named } \\
\text { Entity } 2\end{array}$ & $\begin{array}{l}\text { Relations between } \\
\text { Named Entity } 3 \text { and } \\
\text { Named Entity } 2 \text { used to } \\
\text { be positive. }\end{array}$ & $\begin{array}{l}\text { It is more likely that Named Entity } \\
3 \text { is negative towards Named } \\
\text { Entity } 2, \text { as the cooperation } \\
\text { between them is suspended. } \\
\text { Still negative sentiment cannot be } \\
\text { set, because Named Entity } 3 \text { is } \\
\text { aware of the influence of another } \\
\text { entities. }\end{array}$ \\
\hline 4 & $\begin{array}{l}\text { Named } \\
\text { Entity } 3\end{array}$ & $\begin{array}{l}\text { Named } \\
\text { Entity } 1\end{array}$ & $\begin{array}{l}\text { It is known, that } \\
\text { Named Entity } 1 \\
\text { initiated the suspending } \\
\text { of cooperation between } \\
\text { Entities } 2 \text { and } 3 \text {. } \\
\end{array}$ & $\begin{array}{l}\text { Named Entity } 3 \text { is negative } \\
\text { towards Named Entity } 1 .\end{array}$ \\
\hline
\end{tabular}


The pattern presented in this section describes the relations 1 and 4 in Table 4, but still the intensity of sentiment cannot be formally described. It is obvious that negative sentiment of Named Entity 1 towards Named Entity 3 is the strongest in the example, but it is impossible to add this information to the pattern. Relations 2 and 3 will not be extracted with the pattern, and the idea of expanding pattern structure with additional accusative entity was declined because of lack of evidence of its validity. It is essential for every structure in patterns to be widely presented in texts, otherwise future analysis of new data may lead to the appearance of many incorrect results.

Long context between entities in (4) will not be a cause of failure for the pattern, because our patterns are not restricted in physical distance inside the sentence. Even though it is the economy that is supposed to be the opinion component, the entity in nominative can be included in the sentiment relation, as the economy here is an inner element of the entity.

(4) $N E_{1}$ \{nomn\}, ch'ya ekonomika $v$ dolgosrochnoy perspektive tol'ko okrepnet $v$ usloviyakh osobykh otnosheniy $\mathrm{N} E_{2}\{a b l t\}$

$' N E_{1}\{$ nomn\}, whose economy will grow stronger in the long run in terms of special relations with $\mathrm{NE}_{2}\{$ ablt $\}$ '

Even the longer context between entities may occur within the pattern. Example (5) represents five named entities and several sentiment relations between them. If we do not consider the polarity, the sentence may be transformed into opinions: $\mathrm{NE}_{1} \rightarrow \mathrm{NE}_{2}, \mathrm{NE}_{1} \rightarrow$ $\mathrm{NE}_{3}, \mathrm{NE}_{1} \rightarrow \mathrm{NE}_{4}, \mathrm{NE}_{1} \rightarrow \mathrm{NE}_{5}$, some of them are mutual.

(5) $N E_{1}$ \{nomn\}, kotoryy podderzhival $N E_{2}$ \{accs\}, brosal vyzov izrail'skomu pravitel'stvu i stavil v nevygodnoye polozheniye rukovodstvo $\mathrm{NE}_{3}$ \{gent\}, na etoy nedele reshil primirit'sya $S E_{4}\{a b l t\}$ i vosstanovit' svyazi $N_{5}\{a b l t\}$

$' N E_{1}$ \{nomn\}, which supported $N E_{2}$ \{accs\}, challenged the Israeli government and disadvantaged the leadership of $\mathrm{NE}_{3}$ \{gent\}, this week decided to reconcile with $\mathrm{NE}_{4}$ $\{$ ablt $\}$ and re-establish connections with $\mathrm{NE}_{5}\{a b l t\}$ '

The first relation in (5) $\mathrm{NE}_{1} \rightarrow \mathrm{NE}_{2}$ is not mutual, it is expressed explicitly by a sentiment verb podderzhivat' 'to support'. As for the second one, it is possible to consider inverse relation as a sort of reaction on the behavior of $\mathrm{NE}_{1}$, although, this sort of relationship was not included in the pattern because of possible ambiguity and amount of false positive results. If the rules for establishing relations are set properly, relation $\mathrm{NE}_{1} \rightarrow$ $\mathrm{NE}_{3}$ is supposed to be found within the pattern due to cases of these entities. The last relations $\mathrm{NE}_{1} \rightarrow \mathrm{NE}_{4}$ and $\mathrm{NE}_{1} \rightarrow \mathrm{NE}_{5}$ fall under the construction [NE $\{$ nomn $\} \leftarrow \rightarrow \mathrm{NE}$ $\{$ ablt $\}$, the main pattern structure, so they would be extracted from the sentence, too.

Example (6) presents similar situation. There are mutual sentiment relations between $\mathrm{NE}_{1}$ and $\mathrm{NE}_{4}$, however, two other entities and 23 words are located between them. Still, grammatical constraints imposed on entities allow using the pattern for this opinion.

(6) $N E_{1}\left\{\right.$ nomn\}, sostoyashchaya $v$ Soyuznom gosudarstve $s E_{2}\{$ ablt\}, pytayetsya $v$ to zhe vremya «normalizovat'», kak eto imenuyetsya na ofitsial'nom urovne, otnosheniya s $\mathrm{NE}_{3}\{a b l t\}$ i $\mathrm{NE}_{4}\{a b l t\}$

'NE $E_{1}$ \{nomn\}, which is a Union State with $N E_{2}\{a b l t\}$, is at the same time trying to "normalize", as it is called at the official level, relations with $N E_{3}\{a b l t\}$ and $N E_{4}$ \{ablt\}, 
Mutual sentiment could have been imposed by a word like sanktsii 'sanctions', because the country against that the sanctions are introduced is expected to be negative towards this measure. Nevertheless, this case is not as even as the ones in the Table 2.

\subsection{SOOS - Named Entity - Named Entity}

In the case of elements order, that includes the preceding mutual sentiment indicator, coordinative connecting between entities and more complex structures appeared. Nevertheless, pattern structures can be identified.

Coordinative relations impose that the elements must be in the same case, and this type of connection was included in the pattern in Table 5. When entities followed lexemes konflikt 'conflict', vzaimodeystviye 'interaction', soyuz 'union', dogovorennost' 'agreement', raznoglasiye 'disagreement', otnosheniya 'relations' without preposition they were in genitive case. In the structure with preposition $s$ 'with', entities had ablative.

Table 5. Structure of the pattern SOOS-Named Entity-Named Entity.

\begin{tabular}{|l|l|l|l|l|}
\hline \multicolumn{2}{|c|}{ Indicators of mutual sentiment } & \multicolumn{1}{c|}{$\begin{array}{c}\text { Named Entity } \\
\text { [case\} }\end{array}$} & Connection & $\begin{array}{c}\text { Named } \\
\text { Entity \{case\} }\end{array}$ \\
\hline $\begin{array}{l}\text { konflikt 'conflict' } \\
\text { vzaimodeystviye } \\
\text { 'interaction' } \\
\text { soyuz 'union' } \\
\text { dogovorennost' } \\
\text { 'agreement' } \\
\text { otnosheniya 'relations' } \\
\text { raznoglasiye } \\
\text { 'disagreement' } \\
\text { napryazheniye 'tension' }\end{array}$ & - & \begin{tabular}{l} 
mezhdu \\
'between' \\
\cline { 2 - 5 }
\end{tabular} & $\mathrm{NE}\{$ gent\} $\}$ \\
\hline $\begin{array}{l}\text { sotrudnichestvo 'cooperation' } \\
\text { svyaz 'connection' } \\
\text { otnosheniya 'relations' } \\
\text { konflikt 'conflict' } \\
\text { vzaimodeystviye 'interaction }\end{array}$ & $\mathrm{i}$ 'and' & $\mathrm{NE}\{\mathrm{ablt}\}$ \\
\hline
\end{tabular}

Examples (7) and (8) without coordination are more complicated to be described in the way presented in the paper. Nominative and accusative in Russian can be expressed by similar expressions, that was the reason of their combination into the same group. The word soyuznik 'ally' requires the entity in genitive, the case of the second entity depends on the syntactic roles. Refinement construction takikh kak 'such as' imposes accusative, while the second entity may be the subject of another clause, therefore it may be in nominative case.

(7) soyuznikov $N E_{1}$ \{gent\}, takikh kak $N E_{2}\{$ accs\}

'allies of $N E_{1}$ \{gent\}, such as $N E_{2}\{$ accs\}'

(8) soyuznik $N E_{1}\left\{\right.$ gent\} $-N E_{2}\{$ nomn $\}$

'allies of $N E_{1}\{$ gent $\}-N E_{2}\{$ nomn $\}$ '

Construction with two entities in genitive and ablative cases respectively is more explicit for the analysis. The cases are imposed by features of the indicators of mutual sentiment.

An inversion of the order of cases may occur as a result of impact of the participle like in (9). The structure is opposite to $[\mathrm{NE}\{$ nomn $\} \leftarrow \rightarrow \mathrm{NE}\{$ ablt $\}]$.

(9) uregulirovav raznoglasiya $S E_{1}\{a b l t\}, N E_{2}\{$ nomn\} 
'Having resolved disagreements with $N E_{1}\{a b l t\}, N E_{2}\{n o m n\}$ '

\subsection{Named Entity - Named Entity - SOOS}

The context [NE and NE] will be the most frequent in our sample, entities should be in the same case, usually in the nominative, after they are followed by the indicator of mutual sentiment. In all these cases, a double set of opinions is created. Pattern of this kind can be thought of as the safest for future implementation. Possible structures are presented in Table 6 .

Table 6. Structure of the pattern Named Entity-Named Entity- SOOS.

\begin{tabular}{|c|c|c|c|c|}
\hline Named Entity & Connection & Named Entity & \multicolumn{2}{|c|}{ Indicators of mutual sentiment } \\
\hline \multirow[t]{2}{*}{ NE $\{$ nomn $\}$} & $\mathrm{i}$ 'and' & NE $\{$ nomn $\}$ & Verb & $\begin{array}{l}\text { svyazi } \\
\text { 'connections' } \\
\text { sotrudnichestvo } \\
\text { 'cooperation' }\end{array}$ \\
\hline & & & \multicolumn{2}{|c|}{$\begin{array}{l}\text { sotrudnichat' } \\
\text { 'cooperate' }\end{array}$} \\
\hline NE $\{$ datv $\}$ & i 'and' & NE $\{$ datv $\}$ & $\begin{array}{l}\text { Modal verb, } \\
\text { Verb }\end{array}$ & $\begin{array}{l}\text { svyazi } \\
\text { 'connections' } \\
\text { sotrudnichestvo } \\
\text { 'cooperation' } \\
\text { partnerstvo } \\
\text { 'partnership' } \\
\text { vzaimodeystvie } \\
\text { 'interaction' }\end{array}$ \\
\hline
\end{tabular}

Still other structures that may be useful for mutual sentiment expression have occurred, for example, the sentence span in (10). Ablative case of the first entity is set due to syntactic features, the second entity has accusative case for the same reason. A similar example with the first entity in nominative case is likely to appear in Russian texts.

(10) $s$ NE \{ablt\}, kotoraya schitayet $N E\{$ accs\} soyuznikom 'with $N E\{$ ablt $\}$, that considers $N E\{$ accs\} an ally'

Theoretical syntax may explain other complicated mutual sentiment examples like (11). The predicate predlagat' 'to suggest' has two empty slots to be filled, a direct and an indirect object. The direct object in this example is the indicator of mutual sentiment in accusative case. The indirect object in dative is also typical for this predicate. Mutual sentiment in (11) is not symmetric, because the entities are not equal. The entity in nominative tends to be an explicit subject of opinion, while the inverted opinion just adds some information without being fully independent. The predicate predlagat' 'to suggest' expresses the intention of one entity to establish cooperation but gives no explicit information about sentiment towards the first entity. The implicit component can be supposed: relationship between the entities are good enough to discuss any king of cooperation, therefore mutual sentiment can be set.

(11) $N E\{$ nom\} predlagayet $N E\{$ datv\} voyennoye sotrudnichestvo $\{a c c s\}$

'NE \{nom\} offers $N E$ \{datv\} military cooperation'

For example (12) components of opinion, explicit and implicit information are provided in Table 7. Deep analysis shows that the sentiment between them is not negative, as they 
are members of one political organization. Still, the sentiment is not positive, because NE1 is dissatisfied with NE2, and that is the result of malefactive act of NE2.

(12) NE \{nomn\} nedovol'na, chto NE \{nomn\}- yeye soyuznik po NATO...

$N E$ \{nomn\} is unhappy that NE \{nomn\}, her NATO ally ...

Table 7. Opinions structure of (12).

\begin{tabular}{|l|l|l|l|}
\hline $\begin{array}{c}\text { Subject } \\
\text { of } \\
\text { opinion }\end{array}$ & \multicolumn{1}{|c|}{$\begin{array}{c}\text { Object of } \\
\text { opinion }\end{array}$} & \multicolumn{1}{|c|}{ Explicit information } & \multicolumn{1}{c|}{ Implicit information } \\
\hline $\begin{array}{l}\text { Named } \\
\text { Entity 1 }\end{array}$ & $\begin{array}{l}\text { Named } \\
\text { Entity 2 }\end{array}$ & $\begin{array}{l}\text { Named Entity 1 is dissatisfied by } \\
\text { the behaviour of Named Entity 2. } \\
\text { Named Entity 1 is an ally of } \\
\text { Named Entity 2. }\end{array}$ & $\begin{array}{l}\text { Named Entity 1 shares basic } \\
\text { political views with Named } \\
\text { Entity 1 as they are allies. } \\
\text { They are still allying, but the } \\
\text { sentiment got worse. }\end{array}$ \\
\hline $\begin{array}{l}\text { Named } \\
\text { Entity 2 }\end{array}$ & $\begin{array}{l}\text { Named } \\
\text { Entity 1 }\end{array}$ & $\begin{array}{l}\text { Named Entity 2 is an ally of } \\
\text { Named Entity 1. Entity 2 did something } \\
\text { that caused disapproval of } \\
\text { Named Entity 1. }\end{array}$ & $\begin{array}{l}\text { Named Entity 2 may be a bit } \\
\text { negative towards Named Entity } \\
1 .\end{array}$ \\
\hline
\end{tabular}

Having thoroughly examined the structure of (12) we can see, that general sentiment is rather positive than negative, therefore in binary sentiment evaluation it is to be set as positive. In the case of scale evaluation instead of polarities, sentiment expression nedovol'na 'is unhappy' should lower the sentiment. Some types of texts or text spans cannot be strictly analyzed in terms of binary logic, thence the most appropriate variant should be chosen, even though it does not represent the whole meaning.

Some examples were entangled by specific verbal features, for example, Russian modal vazhno 'it is important', that imposes dative case on entities.

\section{Results}

In the course of analysis three possible patterns of mutual sentiment expression were found. A group of lexemes that impose mutual sentiment can be distinguished from other types of words in sentiment analysis. These lexemes may be sentiment as well, in the case on nonsentiment indicator of mutual sentiment it should be followed by a sentiment expression.

Table 8 shows frequency of each pattern presented in the paper. The most frequent one is the pattern with the indicator of mutual sentiment preceding the entities.

Table 8. Frequency of mutual sentiment patterns.

\begin{tabular}{|l|c|}
\hline \multicolumn{1}{|c|}{ Pattern } & Proportion in data \\
\hline Named Entity - SOOS - Named Entity & 0.34 \\
\hline SOOS - Named Entity - Named Entity & 0.47 \\
\hline Named Entity - Named Entity - SOOS & 0.19 \\
\hline
\end{tabular}

There can be a group of entities in coordinative relation in each pattern instead of a single entity, but the grammatical properties should stay the same as presented in patterns.

\section{Discussion}

A group of lexemes that impose mutual sentiment allows to extract part of implicit information about affectual states, that are even for the native speakers, although sentiment 
analysis system tend to skip these opinions. Moreover, the lists of lexemes presented in the paper may be expanded by using the thesaurus.

Nowadays implicit sentiment extraction is a relevant topic, although the lexemes presented in the paper, were not yet described in their connection to implicit sentiment. To some extent, it is presented in connotation frames, if the verbs are followed by description of relations between opinion elements. The option proposed in the paper is not a complete alternative to frames, but it makes bidirectional sentiment search easier, what is more, patterns can be extended faster than frames.

\section{Conclusions}

The study confirmed the presence of a class of vocabulary with a value of mutual sentiment. Moreover, this lexical class shows regularity in imposing the mutual sentiment to entities, these regularities were presented as patterns. Undoubtedly, all possible structures in the language cannot be described, but even the data presented in this work can serve as material for the sentiment analysis system and affect the results of such systems.

In further studies it is planned to expand the list of tokens with the value of mutual sentiment and validate the received patterns on another language material.

\section{References}

1. N.V. Serdobolskaya, S.Y. Toldova, Proceedings of the International conference Dialogue'2005, 436 (2005)

2. N.V. Serdobolskaya, S.Y. Toldova, Proceedings of Institute for linguistic studies 10(2), 443 (2014)

3. A.V. Zimmerling, Logical analysis of language. The image of man in culture and language, 221 (1999)

4. L. Deng, Y. Choi, J. Wiebe, Proceedings of the 51st Annual Meeting of the Association for Computational Linguistics 2, 120 (2013)

5. L. Deng, J. Wiebe, Proceedings of the 14th Conference of the European Chapter of the Association for Computational Linguistics, 377 (2014)

6. S. Almatarneh, P. Gamallo, Proceedings of the 8th International Conference on Knowledge Engineering and Semantic Web (2017)

7. Y. Chen, S. Skiena, ACL 2, 383 (2014)

8. N.V. Loukachevitch, A.V. Levchik, Proceedings of Language Resources and Evaluation Conference LREC-2016, 1171 (2016)

9. M. Klenner, M. Amsler, Proceedings of the Tenth International Conference on Language Resources and Evaluation (LREC 2016), 2888 (2016)

10. M. Klenner, D. Tuggener, S. Clematide, Proceedings of the 2nd Workshop on Linking Models of Lexical, Sentential and Discourse-level Semantics, 31 (2017)

11. H. Rashkin, E. Bell, Y. Choi, S. Volkova, Proceedings of the 55th Annual Meeting of the Association for Computational Linguistics 2, 459 (2017)

12. V. Yadav, S. Bethard, arXiv (2019) preprint arXiv:1910.11470

13. S.M. Mohammad, P. Sobhani, S. Kiritchenko, ACM Transactions on Internet Technology (TOIT) 17(3) (2017)

14. N. Rusnachenko, N.V. Loukachevitch, DAMDID/RCDL, 186 (2018) 
15. N. Rusnachenko, N.V. Loukachevitch, International Conference on Text, Speech, and Dialogue, 41 (2018)

16. A. Gunda, V. Teratipally, International Research Journal of Engineering and Technology (IRJET) 10(3) (2016)

17. J.R.L. Borin, N.T.S.R. Eide, CLARIN Annual Conference (2018)

18. K.K. Tseng, R.F.Y. Lin, H. Zhou, K.J. Kurniajaya, Q. Li, Electronic Commerce Research 18(1), 65 (2018)

19. U. Farooq, H. Mansoor, A. Nongaillard, Y. Ouzrout, M. Qadir, AJCP 12(5), 470 (2017)

20. N.V. Loukachevitch, G.E. Lashevich, B.V. Dobrov, Proceedings of the 9th Global WordNet Conference (GWC 2018), 35 (2018) 